\title{
Behavior of Heavy Metals during the Agro-Industrial Wastes Gasification
}

\author{
Marcelo Echegaray, Marianela Costante, Alejandra Saffe, Carlos Palacios, Rosa Rodriguez \\ Instituto de Ingeniería Química, Facultad de Ingeniería, Universidad Nacional de San Juan, San Juan, Argentina \\ Email: rrodri@unsj.edu.ar
}

Received May 24, 2013; revised June 27, 2013; accepted July 7, 2013

Copyright (C) 2013 Marcelo Echegaray et al. This is an open access article distributed under the Creative Commons Attribution License, which permits unrestricted use, distribution, and reproduction in any medium, provided the original work is properly cited.

\begin{abstract}
The characterization analysis of three agro-industrial wastes was performed in order to study its thermal gasification. Some analyses such as determination of $\mathrm{Ca}, \mathrm{K}$ and $\mathrm{Mg}$ concentration and determination of three representative toxic metals concentration $\mathrm{Cd}, \mathrm{Cr}$ and $\mathrm{Pb}$ in all its oxidation states and the fundamental state, were carried out. The heavy metals concentration was also determined in the ashes obtained during the gasification process. The mobility of these elements was studied through three leaching tests. The behavior of heavy metals, sulfur and chlorine compounds, was predicted considering the presence of water vapor, syngas, $\mathrm{Ca}, \mathrm{Mg}, \mathrm{K}, \mathrm{Si}, \mathrm{Al}$ and other ash components. The heavy metals are not more concentrated in the gasification ash; these pollutants are released during this process. $\mathrm{Ca}, \mathrm{Mg}$ and $\mathrm{K}$ presence in these residues would promote the pollutants retention. The ash of the studied waste can be disposed in controlled landfills or used in road construction, according to the obtained results during the leaching test DIN-DEV S4. The obtained results in the leaching test EPA 1311 TLCP classify these gasification ashes as no toxic waste.
\end{abstract}

Keywords: Gasification; Agro-Industrial Wastes; Ash

\section{Introduction}

The agro-industrial sector produces a significant environmental impact in specific geographical areas, due to generated waste, such as the Cuyo Region, Argentina. A strategy in this sense is to propose an appropriate agroindustrial waste management in order to minimize the emitted pollutants, transforming them into high valueadded products or renewable energy source, tending to "Zero-waste".

During the 2011 harvest, 690,000 tons were used to produce wine, generating nearly $200,000 \mathrm{~kg}$ of stalks without considering other solid wastes, such as marcs and wine dregs. The latter are generally used for the byproducts recovery.

However, reuse and/or disposal of exhausted marcs and wine dregs are a current problem in the region, because their disposal in landfills is not environmentally convenient due to they are not fully reused and large volumes are generated, requiring significant areas of land for their disposal. The waste from the fruits and vegetables canning industry have a high water content and, in many cases, significant amounts of lignocellulose materials. The final disposal in landfills is also performed in this region.
Moreover, there is a growing global interest in the technologies development for the exploitation of renewable energy sources because of environmental and economic reasons. In particular, due to the continuous increase in the cost of fossil energy resources, biomass is considered as one of the most promising and viable alternatives. Energy from waste is an important component of integrated waste management. One of the major limitations in the use of biomass wastes for energy production is its availability and moderate calorific value resulting in a low production and high costs compared to fossil fuels. The reduction of gases emissions, such as $\mathrm{SO}_{\mathrm{x}}$ and greenhouse gases; however, is agreed with the policies of current pollution control [1].

The energy conversion technologies and the biomassbased systems are the only electricity renewable source excluding hydro power, a crucial fact for future electricity production. A technology with a great future is the gasification. After more than 30 years of research, there is now worldwide interest in the use of $\mathrm{H}_{2}$ as an alternative transportation fuel [2].

The steam gasification of waste is an attractive process for producing $\mathrm{H}_{2}$-rich gas [3-5]. This process has been developed to reduce the amount of undesired products 
and the coke formation rate [6]. Furthermore, a vapor excess can easily be separated by condensation. Regarding existing gasification technologies, the fluidized bed is attractive because it provides a good contact between gas and solid, uniform temperatures and high reaction rates, compared to the fixed bed gasification [7]. Moreover, fluidized beds have a high flexibility in the feed in terms of shape, size and composition, as well as a wide range of operational and safety capabilities [8].

Considering the heavy metals, they are enriched in the solid waste of gasification (fly ash and bottom), and they are also released in the gas stream or tar. Their vaporization depends on the initial chemical speciation, gasification atmosphere, the fluid dynamics, the kinetics of heavy metals diffusion in the solid particles and reaction kinetics between the heavy metals and major components of ash $[9,10]$.

The ash disposal conditions as well as their reuse are established by the trace elements concentration and their mobility [8].

In view of these aspects, the heavy metals behavior during agro-industrial waste gasification, their mobility out the ash matrix and the toxicity determination of generated solid waste during this process were studied.

\section{Experimental}

Agro-industrial residues from canning and wine sector were used: peach pits, stalks and marc, respectively. These industries are located in the province of San Juan, Argentina.

In order to obtain the ash, a differential reactor was used. It is constructed of AISI 316 stainless steel. It is constituted by a cylinder with $50 \mathrm{~mm}$ of diameter and 30 $\mathrm{mm}$ of length, heated by an electric resistance with electronic temperature control. Figure 1 shows a used reactor scheme.

According to Kurkela et al. [11] (2006), for feeds with high alkali content, low gasification temperatures $(\mathrm{T}=$ $750^{\circ} \mathrm{C}-850^{\circ} \mathrm{C}$ ) and the steam addition are recommended to prevent the agglomeration in the fluidized reactor.

Skoulou et al. (2008) [12] studied the effect of temperature $\left(\mathrm{T}=750^{\circ} \mathrm{C}-850^{\circ} \mathrm{C}\right.$ ) and air equivalent ratio (ER $=0.2-0.4$ ) in biomass gasification into a fluidized bed (ER is the ratio between the air sub-stoichiometric and the air required for complete combustion amounts). Experimental results showed that working at $750^{\circ} \mathrm{C}$ and ER equal to 0.2 , the $\mathrm{H}_{2}$ optimal content in the syngas is obtained.

Taking into account these experimental results obtained by other researchers, the used gasifying agent was the steam and air mixture. The ER was equal to 0.2 and the temperature equal to $750^{\circ} \mathrm{C}$. The gasifying agent (airsteam mixture) entered from the reactor bottom. The syngas exited at the top.

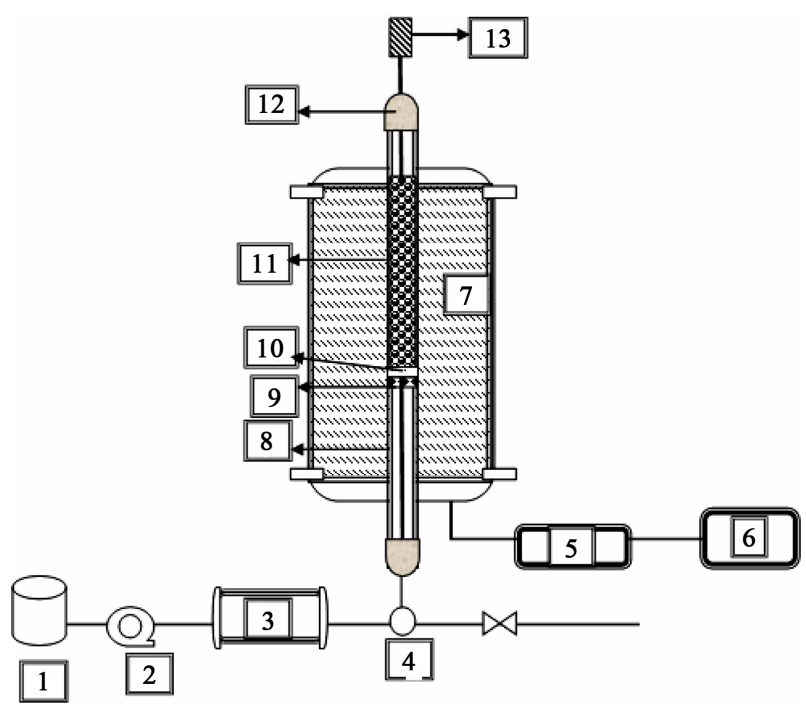

Figure 1. Used reactor scheme. 1: water tank; 2: pump; 3: evaporator; 4: mixer; 5: power supply; 6: temperature controller; 7: electric resistance; 8: reactor; 9: support steel; 10: porous metal mesh; 11: agro-industrial wastes; 12: gas output; 13: thermocouple.

For each test, the reactor is loaded with 50 to $60 \mathrm{~g}$ of agro-industrial wastes. The obtained ashes in this reactor are considered with similar characteristics as the ash bottom obtained in a fluidized bed reactor [13].

\subsection{Agro-Industrial Wastes Characterization}

The weight loss at $105^{\circ} \mathrm{C}$ (ASTM D3173-87, Standard Test Method for Moisture in the Analysis Sample of Coal and Coke, 1996), the ash and the organic matter contents (ASTM D3172-89(2), Standard Practice for Proximate Analysis of Coal and Coke, 2002), the concentrations of $\mathrm{Cd}, \mathrm{Cr}$ and $\mathrm{Pb}$ were determined for the studied agro-industrial wastes. In order to determine the heavy metal concentrations, first, the samples were digested according to EPA digestion (US Environmental Protection Agency, 1982). Then, the heavy metals concentrations were determined using a visible light spectrophotometer (HACH DR/2010 Spectrophotometer Datalogging portable).

$\mathrm{Cd}, \mathrm{Pb}$ and $\mathrm{Cr}$ were considered due to their behaviors during heat treatments which are different. Cd vaporizes and it is not remained in the ash, $\mathrm{Pb}$ shows an intermediate behavior, and $\mathrm{Cr}$ is remained in solid residue of gasification [14].

In order to determine the influence of the presence of $\mathrm{Ca}, \mathrm{Mg}$ and $\mathrm{K}$ in this biomass gasification, their concentration was determined in the studied agro-industrial wastes, using the atomic absorption method.

\subsection{Heavy Metals Mobility of the Ash Mineral Matrix}

With the purpose of study the heavy metals mobility of 
the ash mineral matrix, the $\mathrm{Cd}, \mathrm{Pb}$ and $\mathrm{Cr}$ concentrations were determined in the solid wastes of gasification, using the analytical techniques described above. This study is very important because it determines the final disposal and/or further use.

Particularly, the use of the gasification ash in different applications contributes to the sustainability of biomass use in power generation. Several options are discussed: use as fertilizer, as a building material or as fuels [15]. The heavy metals mobility was studied by three different tests:

- The German test, DIN 38414 part 4 (DEV S4, German Standard Procedure for Water, Wastewater and Sediment Testing, 1984): It is used to classify the waste. The limits of heavy metals concentrations in the leaching solution are expressed in $\mathrm{mg} / \mathrm{l}$ for disposal in landfill (Class 1) and for the ash use in road construction [16].

- The US EPA TCLP 1311 test (Toxicity Characteristic Leaching Procedure. Methods for Evaluating Solid Waste, 1992): It determines the potential leaching of organic and inorganic material in liquid, solid and multi-phase, of the residues in contact with groundwater. This test simulates landfill leaching conditions and the ash can be classified as toxic or not [17].

- The Dutch NEN 7341 test (Determination of the Leaching Behavior of Granular Materials: Availability Test, 1993): This test determines the maximum proportion of heavy metals leached from different wastes such as ash. This is achieved by leaching of finely milled solid (maximizing the contact surface) and using a high liquid/solid ratio. The metal fixation in the solid matrix is predicted with this test $[18,19]$.

The DIN test uses the weaker leaching agent, distilled water, and the test NEN the stronger, nitric acid.

\section{Results and Discussion}

The results of the agro-industrial wastes characterization are shown in Table 1. The highest ash and water content were found in the stalk. A high water content increases the energy requirements to carry out the gasification, decreasing the efficiency of the plant, but on the other hand, it improves the synthesis gas quality by increasing the content of $\mathrm{CO}_{2}, \mathrm{CH}_{4}$ and $\mathrm{H}_{2}$ [20] and decreasing hydrocarbons and tars levels. In order to optimize the gasifier operation, Pfeifer et al. [21] determined the optimum content equal $20 \%$ to $40 \%$ by weight at low temperatures heating.

Regarding the ash content, a low percentage of it will minimize the production of fly and the bottom ash. In general, these solids contain significant amounts of unreacted carbon and sulfur [22].

$\mathrm{Cd}, \mathrm{Cr}$ and $\mathrm{Pb}$ are present in the composition of studied agro-industrial wastes. The stalks and the peach pits
Table 1. Results of proximate analysis. Determination of heavy metals and $\mathrm{Ca}, \mathrm{K}$, and $\mathrm{Mg}$ concentrations in agroindustrial wastes.

\begin{tabular}{cccc}
\hline & Stalk & Marc & Peach pits \\
\hline Weight loss at $\mathbf{~ 1 0 5}^{\circ} \mathbf{C}$ (dry basis \%) & 73.23 & 55.06 & 35.57 \\
Ash (dry basis \%) & 6.30 & 5.08 & 0.73 \\
Organic matter (dry basis \%) & 93.7 & 94.92 & 99.27 \\
$\mathbf{C d}(\mathbf{m g} / \mathbf{k g}$ dry basis) & 1.25 & 0.02 & 1.25 \\
$\mathbf{C r}(\mathbf{m g} / \mathbf{k g}$ dry basis) & 25.00 & 37.50 & 3.125 \\
$\mathbf{P b}(\mathbf{m g} / \mathbf{k g}$ dry basis) & 75.00 & 82.92 & 0.94 \\
$\mathbf{C a}(\mathbf{g} / \mathbf{k g}$ dry basis) & 2.25 & 2.96 & 0.02 \\
$\mathbf{K}(\mathbf{g} / \mathbf{k g}$ dry basis) & 19.23 & 7.38 & 7.15 \\
$\mathbf{M g}(\mathbf{g} / \mathbf{k g}$ dry basis) & 0.58 & 0.46 & 0.44 \\
\hline
\end{tabular}

presented the highest Cd concentrations. With respect to $\mathrm{Cr}$ and $\mathrm{Pb}$, the highest concentrations were found in winemaking waste.

Considering the obtained results by analyzing the gasification ash (Table 2), the highest $\mathrm{Cd}$ and $\mathrm{Pb}$ concentrations were found in the marcs ash. For $\mathrm{Cr}$, the highest concentrations were found in the stalks ash, in this case the metal concentrations is more variable (between 3.12 and $15.86 \mathrm{mg} \mathrm{Cr} / \mathrm{kg}$ of dry weight waste).

Comparing the found heavy metals concentrations in the stalks and their ash, the Cd concentration variation is very small and the $\mathrm{Cr}$ and $\mathrm{Pb}$ concentrations of stalks are higher than these concentrations in their ash. In the case of the marcs and their ash, the Cd is more concentrated in the gasification solid waste, but the $\mathrm{Cr}$ and $\mathrm{Pb}$ concentrations are higher in the marcs. Comparing the concentrations of three heavy metals found in peach pits and their ash, a significant variation is not observed.

On this point, it is important to explain the heavy metals behavior during the biomass thermal treatment. When organic matter is consumed during any heat treatment, heavy metals are exposed to a hot and oxygen-depleted atmosphere, adjacent to the particle, presenting one of the following behaviors [9]:

1) They vaporize directly in the initial chemical species;

2) They react with a compound present in the atmosphere and then, they vaporize;

3) They remain unreacted in the mineral matrix.

The vaporized species enter in the gas flow where they react or condense. The condensed species form new particles (homogeneous nucleation) or they are deposited on the present particles surfaces (heterogeneous deposition). Homogeneous nucleation gas explains the substantial amount of very fine metal particles (diameter between 0.02 to 1 microns) found in the effluent gases. The heterogeneous deposition occurs in larger particles and they 
Table 2. Heavy metals concentrations in the ash.

\begin{tabular}{cccc}
\hline Ash & $\mathbf{C d}(\mathbf{m g} / \mathbf{k g})$ & $\mathbf{C r}(\mathbf{m g} / \mathbf{k g})$ & $\mathbf{P b}(\mathbf{m g} / \mathbf{k g})$ \\
\hline Stalk & 1.22 & 15.86 & 14.07 \\
Marc & 1.43 & 11.56 & 30.27 \\
Peach pits & 1.09 & 3.12 & 0.63 \\
\hline
\end{tabular}

can be captured by the pollution control systems. To promote the heterogeneous deposition, it is necessary to limit the formation of fine metal particles.

The species formation with lower oxidation states than the initial states are favored by the reducing conditions. Furthermore, these metals may react with other released elements, as chlorine or sulfur. These new species are generally more volatile than the metal species present in the agro-industrial waste. The heavy metals volatilization during the gasification depends of their speciation and the gasification atmosphere.

Taking into account the heavy metals partition during gasification in fluidized bed reactor, the turbulence conditions during its operation cause a significant production of fly ash with high concentrations of these elements. The heavy metals partition during heat treatments in fluidized bed is governed by the fluid dynamics, the kinetics of heavy metals diffusion in the ash particles and reaction kinetics between the heavy metals and the ash components [10].

The chemical composition of the mineral matrix has a great influence on the kinetics of heavy metals vaporization; it determines the bonding strength between the mineral matrix and these elements, as well as the time required for diffusion out of the particle. Thus, basic species in the matrix $\left(\mathrm{SiO}_{2}, \mathrm{Al}_{2} \mathrm{O}_{3}, \mathrm{CaO}\right)$ can react with these metals encapsulating them in the particle center [8]. The $\mathrm{CdO}(\mathrm{s}), \mathrm{Cr}_{2} \mathrm{O}_{3}$ (s) and $\mathrm{PbO}$ (s) may react with $\mathrm{HCl}$, according to the following reaction:

$$
\mathrm{MeO}(\mathrm{s})+2 \mathrm{HCl}(\mathrm{g}) \rightleftharpoons \mathrm{MeCl}_{2}(\mathrm{~g})+\mathrm{H}_{2} \mathrm{O}(\mathrm{g})
$$

The used steam during the gasification phenomenon affects the reaction equilibrium and the heavy metals retention as oxides in produced solid waste [23]. A high water content of feed waste promotes this retention. Then, during the waste gasification using steam, the reaction is displaced to the left causing the formation of metal oxides. Notably, Mojtahedi and Salo [24] observed the presence of heavy metal chlorides in volatile phase when the gasification was carried out at high temperature.

According to Park et al. [25], $\mathrm{MeO}$ can react with the syngas according to the Reactions (2) and (3):

$$
\begin{aligned}
& \mathrm{MeO}(\mathrm{s})+\mathrm{H}_{2}(\mathrm{~g}) \rightleftharpoons \mathrm{Me}(\mathrm{s})+\mathrm{H}_{2} \mathrm{O}(\mathrm{g}) \\
& \mathrm{MeO}(\mathrm{s})+\mathrm{CO}(\mathrm{g}) \rightleftharpoons \mathrm{MeC}(\mathrm{s})+\mathrm{O}_{2}(\mathrm{~g})
\end{aligned}
$$

when these reactions occur, the heavy metal gradually diffuses to the particle surface subsequently vaporized.
These reactions can be inhibited by the addition of natural zeolite.

Vervaeke et al. [26] observed the augmentation of Cd and $\mathrm{Pb}$ concentrations in the fly ash comparing with bottom ash, during wood gasification in fixed bed; however, $\mathrm{Cr}$ remained in the bottom ash. Pinto et al. [22] detected higher $\mathrm{Pb}$ concentrations in the ash captured by cyclones comparing with bottom ash, confirming the above mentioned studies.

The amount of heavy metals which remains in the ashdecreases when the working temperature is high, close to $900^{\circ} \mathrm{C}$, and the synthesis gas quality increases.

According to Wei et al. [27], the sand, used as the bed material, adsorbs heavy metals, decreasing their concentrations in exit flow gas. The heavy metals release increases when the adsorption efficiency of this material decreases.

On the other hand, some metals such as Ca inhibit the bed material agglomeration, maintaining the fluidization quality and sand mixed with the biomass to be gasified. Then, Ca improves the fluidization delaying the heavy metals release [28,29].

Cui et al. [30] observed that most of the heavy metals are enriched in the exit gas flow. The experimental results are consistent with these observations. Approximately $70 \%$ of trace elements found in the synthesis gas, including three studied heavy metals, come from the gasified biomass and about 25\% from gasification system.

Considering the alkali elements contents in the studied biomass, the Ca concentrations vary in a small range, except for the peach pits. For $\mathrm{K}$, the found concentration in the stalk is very high compared to these concentrations in the marc and peach pits. The Mg concentrations in all analyzed residues vary in a small range.

If the gasification is carried out into a fluidized bed reactor, it is important to consider the biomass tendency to separate from the bed due to its low density, as well as the elutriation tendency of $\mathrm{C}$ small particle.

On the other hand, the gasification ash are inert and no involved in chemical equilibrium of the gasification reactions but, it may have a catalytic effect, accelerating the char gasification reaction with steam, especially when the ash contains metal oxides as $\mathrm{K}_{2} \mathrm{O}, \mathrm{CaO}, \mathrm{MgO}, \mathrm{P}_{2} \mathrm{O}_{5}$, etc. [31].

Table 3 shows the principal conditions of lixiviation tests and relative ratio of the studied heavy metals found in the leaching solution.

Taking into account these results, the three metals were detected in leaching tests DIN-DEVS4, except to peach pits ash. Cd had higher mobility in leaching test DIN-DEVS4 for the marc ash. The $\mathrm{Pb}$ and $\mathrm{Cr}$ showed the highest mobility for the peach pits ash.

Considering the EPA-TLCP test results, all metals had the highest mobility in the case of the peach pits ash. 
Table 3. Main characteristics of the leaching tests. Relative ratio of the studied heavy metals found in the leaching solution.

\begin{tabular}{|c|c|c|c|c|c|c|}
\hline Lixiviation test & Leaching solution & Time (h) & pH final value & Cd (\%) & Cr (\%) & $\mathbf{P b}(\%)$ \\
\hline DIN-DEV S4 & Distilled water & 24 & Final pH: 9 & & & \\
\hline Stalk ash & & & & 66.64 & 1.50 & 2.75 \\
\hline Marc ash & & & & 15.62 & 0.33 & 5.03 \\
\hline Peach pits ash & & & & 0.00 & 85 & 100 \\
\hline EPA-TLCP 1311 & Acetic acid & 18 & Final pH: 4.5 & & & \\
\hline Stalk ash & & & & 0.00 & 25,00 & 3,01 \\
\hline Marc ash & & & & 15.62 & 6.67 & 4.04 \\
\hline Peach pits ash & & & & 100 & 32.10 & 100 \\
\hline NEN 7341 & Nitric acid & $\begin{array}{l}3 \text { (step 1) } \\
3 \text { (step 2) }\end{array}$ & $\begin{array}{l}7 \text { (step 1) } \\
4 \text { (step 2) }\end{array}$ & & & \\
\hline Stalk ash & & & & 33.36 & 24.00 & 3.86 \\
\hline Marc ash & & & & 0.00 & 3.01 & 5.52 \\
\hline Peach pits ash & & & & 0.00 & 100 & 100 \\
\hline
\end{tabular}

Regarding NEN 7341 test results, Cd was not released from the peach pits and marcs ash, the $\mathrm{Cr}$ and $\mathrm{Pb}$ had highest mobility from the peach pits ash. Heavy metals mobility did not vary with the $\mathrm{pH}$ variation.

Established limit concentrations in the leachate solution for Cd by DIN 38414 test are 0.05 and $0.005 \mathrm{mg} / \mathrm{l}$ to be placed in a landfill or used in the road construction, respectively. For $\mathrm{Pb}$, these limit concentrations are 0.2 and $0.05 \mathrm{mg} / \mathrm{l}$, respectively. The $\mathrm{Cr}$ is not regulated in this test. Taking into account the $\mathrm{Cd}$ and $\mathrm{Pb}$ concentrations in leachate solution from the studied wastes ash, it is concluded that these solid residues can be disposed in landfills or used in road construction.

The limit concentrations in the leachate solution, according to EPA test-TLCP 1311 are 1, 5 and $5 \mathrm{mg} / \mathrm{l}$ for $\mathrm{Cd}, \mathrm{Cr}$ and $\mathrm{Pb}$, respectively.

Figure 2 show the relative ratio of the studied heavy metals found in the leaching solution for each tests.

In order to analyze the ash reuse as fertilizer, it is important to consider that the ash can be only $\mathrm{K}$ source, because they do not contain nitrogen and the phosphorus is content in forms with very poor solubility. The Mg and Ca content can improve quality especially in soil $\mathrm{pH}$ control. Considering this aspect and the retention of these elements in the solid matrix, it is concluded that the gasification ash from the stalks are most suitable for this use.

The ash from fluidized bed has constituent material of the bed (sand) and can be reused in road construction or concrete; however, its content of carbon, alkali and chlorine does not make it appropriate to be used as a construction material.

Considering the reuse as fuel, it is important to emphasize that the gasification ash, in general, have a significant amount of unburned carbon. This reuse is obviously the best choice because it has the same purpose as the original material: power generation, however, the heavy metals behavior must be considered [15].

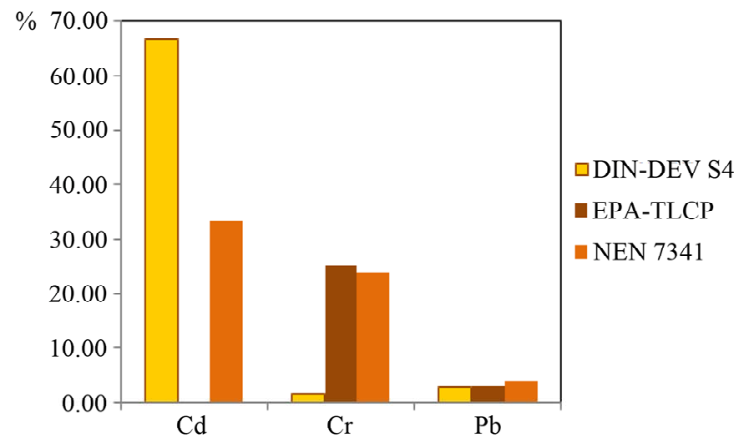

Figure 2. Relative ratio of the studied heavy metals found in the leaching solution for stalk ash.

\section{Conclusions}

The studied agro-industrial wastes have higher water content than $20 \%$. Taking into account previous research, these wastes should be dried before the gasification in order to optimize the process yield. The residues analyzed have low ash contents. This aspect will have a significant impact on the obtained amount of fly and bottom ash from the gasification process.

The studied heavy metals are not more concentrated in the ash; therefore, they are released as gas, fly ash (homogeneous or heterogeneous nucleation) or tar.

The Ca content improves the retention of heavy metals. The improvement of the fluidization conditions produces their retention.

The results obtained in the leaching test DIN-DEV S4 suggest that the ash of this waste can be disposed in controlled landfills or used in road construction. It should be noted that the other parameters set by this test must be analyzed. The results obtained in the leaching test EPA 1311 TLCP are smaller than the limits set by the test.

The gasification ash can be reused for power generation or as fertilizers. In both cases, it will be necessary to perform an economic evaluation. The power generation 
reuse is most appropriate because it increases the gasification plant efficiency, but the heavy metals content in the ashes must be considered in order to minimize the environmental impact.

\section{REFERENCES}

[1] H. Groscurth, A. Almeida, A. Bauen, F. Costa, J. Ericsson and J. Giegrich, "Total Costs and Benefits of Biomass in Selected Regions of the European Union,” Energy, Vol. 25, No. 11, 2000, pp. 1081-1095. doi:10.1016/S0360-5442(00)00016-5

[2] A. Bridgwater, "The Technical and Economic-Feasibility of Biomass Gasificationfor Power-Generation,” Fuel, Vol. 74, No. 5, 1995, pp. 631-653. doi:10.1016/0016-2361(95)00001-L

[3] M. Baratieri, P. Baggio, L. Fiori and M. Grigiante, "Biomass as an Energy Source: Thermodynamic Constraints on the Performance of the Conversion Process," Bioresource Technology, Vol. 99, No. 15, 2008, pp. 7063-7073. doi:10.1016/j.biortech.2008.01.006

[4] C. Franco, F. Pinto, I. Gulyurtlu and I. Cabrita, "The Study of Reactions Influencing the Biomass Steam Gasification Process,” Fuel, Vol. 82, No. 7, 2003, pp. 835-842. doi:10.1016/S0016-2361(02)00313-7

[5] D. Ross, R. Noda, M. Horio, A. Kosminski, P. Ashman and P. Mullinger, "Axial Gas Profiles in a Bubbling Fluidized Bed Biomass Gasifier,” Fuel, Vol. 86, No. 10-11, 2007, pp. 1417-1429. doi:10.1016/j.fuel.2006.11.028

[6] G. Taralas and M. Kontominas, "Pyrolysis of Solid Residues Commencing from the Olive Oil Food Industry for Potential Hydrogen Production,” Journal of Analytical and Applied Pyrolysis, Vol. 76, No. 1-2, 2006, pp. 109116. doi:10.1016/j.jaap.2005.08.004

[7] P. Foscolo, A. Germanà, N. Jand and S. Rapagnà, "Design and Cold Model Testing of a Biomass Gasifier Consisting of Two Interconnected Fluidized Beds," Powder Technology, Vol. 173, No. 3, 2007, pp. 179-188. doi:10.1016/j.powtec.2007.01.008

[8] R. Rodriguez and S. Udaquiola, "Gasificación Térmica de Residuos de la Agroindustria, San Juan,” Proceedings of 2th Congreso Iberoamericano, Hidrógeno y Fuentes Sustentables de Energía, Hyfusen, 2009, pp. 110-115.

[9] S. Abadanes, "Comportement des Metauxlourdsdans les Procédéséchetsménagers,” Thèse du Doctorat, Université de Perpignan, 2001.

[10] J. Toledo, J. Corella and L. Corella, "The Partitioning of Heavy Metals in Incineration of Sludges and Waste in a Bubbling Fluidized Bed. 2. Interpretation of Results with a Conceptual Model,” Journal of Hazardous Materials, Vol. 126, No. 1-3, 2005, pp. 158-168. doi:10.1016/j.jhazmat.2005.06.021

[11] E. Kurkela, M. Kurkela and A. Moilanen, "Fluidised-Bed Gasification of High-Alkali Biomass Fuels,” Proceedings of Science in Thermal and Chemical Biomass Conversion, 2006, pp. 662-676.

[12] V. Skoulou, G. Koufodimos, Z. Samaras and A. Zabaniotou, "Low Temperature Gasification of Olive Kernels in a 5-kW Fluidized Bed Reactor for H2-Rich Producer Gas,” International Journal of Hydrogen Energy, Vol. 33, No. 22, 2008, pp. 6515-6524. doi:10.1016/j.ijhydene.2008.07.074

[13] R. Rodriguez, M. Echegaray, R. Y. Castro and S. Udaquiola, "Distribución Química de Plomo, Cromo y Cadmio en lodos Cloacales y sus Cenizas," Revista Académica de la Facultad de Ingeniería de la Universidad Autónoma de Yucatán, Vol. 11, No. 2, 2007, pp. 31-38.

[14] R. Rodriguez, C. Palacios, S. Udaquiola, G. Flamant, O. Martínez and G. Mazza, "Estudio de la Vaporización de Elementos Traza Durante la Combustión de Barros Cloacales,” Rev. Facultad De Ingeniería -Universidad De Antioquia, Vol. 55, 2010, pp. 64-73.

[15] J. Pels, D. De Nie and J. Kiel, "Utilization of Ashes from Biomass Combustion and Gasification," Proceedings of the 14th European Biomass Conference \& Exhibition, Bioenergy NoE Partner Publications, 2009.

[16] DIN 38414-S4, "German Standard Procedure for Water, Wastewater and Sediment Testing (Group S),” Determination of Leachability by Water, Institutfür Normung, Berlín, Alemania, 1984.

[17] EPA TCLP, "Toxicity Characteristic Leaching Procedure. Method 1311. Test Methods for Evaluating Solid Waste," US Environmental Protection Agency, Washington DC, 1992.

[18] NEN 7341, "Determination of the Leaching Behavior of Granular Materials: Availability Test,” Netherlands Normalization Institute, Delft, Holanda, 1993.

[19] H. Van Der Sloot, D. Kosson, T. Eighmy, R. Comans and O. Hjelmar, “Approach towards International Standarization: A Concise Scheme for Testing of Granular Waste Leachability," Proceeding of the International Conference on Environmental Implications of Construction Materials and Technology Developments, Environmental Aspects of Construction with Waste Materials, Elsevier Science, 1994, pp. 453-466. doi:10.1016/S0166-1116(08)71478-X

[20] L. Xie, T. Li, J. Gao, X. Fei, X. Wu and Y. Jiang, "Effect of Moisture Content in Sewage Sludge on Air Gasification,” Journal of Fuel Chemistry and Technology, Vol. 38, No. 5, 2010, pp. 615-620. doi:10.1016/S1872-5813(10)60048-5

[21] C. Pfeifer, S. Koppatz and H. Hofbauer, "Steam Gasification of Various Feedstocks at a Dual Fluidised Bed Gasifier: Impacts of Operation Conditions and Bed Materials," Biomass Conversion and Biorefinery, Vol. 1, No. 1, 2011, pp. 39-53. doi:10.1007/s13399-011-0007-1

[22] F. Pinto, H. Lopes, R. Andre, I. Gulyurtlu and I. Cabrita, "Effect of Catalysts in the Quality of Syngas and ByProducts Obtained by Co-Gasification of Coal and Wastes. 2: Heavy Metals, Sulphur and Halogen Compounds Abatement," Fuel, Vol. 87, No. 7, 2008, pp. 1050-1062. doi:10.1016/j.fuel.2007.06.014

[23] R. Rodriguez, S. Acosta, A. Saffe and S. Udaquiola, "Predicción de la Partición de Cd, Cr y Pb Durante la Gasificación de Residuos Agroindustriales,” Proceedings of the Congreso Internacional de Ciencia y Tecnología Ambiental, Asociación Argentina para el Progreso de las 
Ciencias, Mar del Plata, Buenos Aires, 2012, pp. 422427.

[24] W. Mojtahedi and K. Salo, "Fate of Alkali and Trace Metals in Biomass Gasification,” Biomass and Bionergy, Vol. 15, No. 3, 1998, pp. 263-267. doi:10.1016/S0961-9534(98)00019-1

[25] K. Park, J. Hyun, S. Maken, S. Jang and J. Park, "Vitrification of Municipal Solid Waste Incinerator Fly Ash Using Brown's Gas,” Energy Fuels, Vol. 19, No. 1, 2005, pp. 258-262. doi:10.1021/ef049953z

[26] P. Vervaeke, F. Tack, F. Navez, J. Martin, M. Verboo and N. Lust, "Fate of Heavy Metals during Fixed Bed Downdraft Gasification of Willow Wood Harvested from Contaminated Sites,” Biomass Bioenergy, Vol. 30, No. 1, 2006, pp. 58-65. doi:10.1016/j.biombioe.2005.07.001

[27] X. Wei, U. Schnell and K. Hein, "Behaviour of Gaseous Chlorine and Alkali Metals during Biomass Thermal Utilization,” Fuel, Vol. 84, No. 7-8, 2005, pp. 841-848.

[28] C. Lin, H. Kuo, M. Wey, S. Chang and K. Wang, “Inhibi- tion and Promotion: The Effect of Earth Alkali Metals and Operation Temperature on Particle Agglomeration/ Defluidization during Incineration in Fluidized Bed," Powder Technology, Vol. 189, No. 1, 2009, pp. 57-63. doi:10.1016/j.powtec.2008.06.003

[29] C. Lin, M. Tsai and C. Chang, "The Effects of Agglomeration/Defluidization on Emission of Heavy Metals for Various Fluidized Parameters in Fluidized-Bed Incineration,” Fuel Processing Technology, Vol. 91, No. 1, 2010, pp. 52-61. doi:10.1016/j.fuproc.2009.08.012

[30] H. Cui, S. Turn, V. Keffer, D. Evans, T. Tran and M. Foley, "Study on the Fate of Metal Elements from Biomass in a Bench-Scale Fluidized Bed Gasifier," Fuel, Vol. 108, 2013, pp. 1-12. doi:10.1016/j.fuel.2011.07.029

[31] J. Song, Y. Sung, T. Yu, Y. Choi and U. Lee, “Optimization of Biomass Gasification for F-T Bio-Diesel Synthesis," Proceedings of the 20th International Conference on Fluidized Bed Combustion, Part 5, 2010, pp. 633-635. 